\title{
Status gingiva pada pasien pengguna gigi tiruan cekat di RSGM PSPDG Fakultas Kedokteran Universitas Sam Ratulangi Manado
}

\author{
${ }^{1}$ Melinda H. Laoh \\ ${ }^{2}$ Krista V. Siagian \\ ${ }^{3}$ Shane H. R. Ticoalu \\ ${ }^{1}$ Kandidat Skripsi Program Studi Pendidikan Dokter Gigi Fakultas Kedokteran \\ ${ }^{2}$ Program Studi Pendidikan Dokter Gigi Fakultas Kedokteran \\ ${ }^{3}$ Bagian Anatomi-Histologi Gigi Fakultas Kedokteran \\ Universitas Sam Ratulangi Manado \\ E-mail: melindalaoh41@gmail.com
}

\begin{abstract}
The use of fixed denture aims to preserve and maintain the remained teeth and the whole mastication system properly. The use of fixed denture can be perceived as original teeth because it cannot be removed by the patient. However, fixed denture can also have an impact on periodontal tissues, such as gingivitis. This can probably occur due to the inappropriate process of the fixed denture that does not meet the requirements. This study was aimed to determine the gingival status of fixed denture users at RSGM PSPDG University of Sam Ratulangi Manado. This was a descriptive study with a cross sectional design. Population was all patients who used fixed denture made at RSGM PSPDG University of Sam Ratulangi Manado. Respondents were 31 people obtained by using total sampling method. Data consisted of checking sheets of gingival status with gingival index. The results showed that gingival status of 29 fixed denture users (93.6\%) was in mild inflammation category (gingival index 0.7). Conclusion: In this study, most fixed denture users had gingival status of mild inflammation category.
\end{abstract}

Keywords: gingival status, fixed denture

\begin{abstract}
Abstrak: Penggunaan gigi tiruan cekat (GTC) dimaksudkan untuk mempertahankan dan memelihara kesehatan gigi geligi yang masih ada beserta seluruh sistem penguyahan supaya dapat berfungsi dengan baik. Penggunaan GTC dapat dirasakan seperti gigi asli karena tidak dapat dilepas oleh pasien. Penggunaan GTC juga dapat berdampak pada jaringan periodontal seperti gingivitis. Hal tersebut dapat terjadi bila dalam pembuatannya tidak memenuhi syarat-syarat pembuatan gigi tiruan cekat. Penelitian ini bertujuan untuk mengetahui status gingiva pada pasien pengguna GTC di RSGM PSPDG Fakultas Kedokteran Universitas Sam Ratulangi Manado. Jenis penelitian ialah deskriptif dengan desain potong lintang. Populasi penelitian ialah seluruh pasien yang menggunakan GTC yang dibuat di RSGM PSPDG Fakultas Kedokteran Universitas Sam Ratulangi Manado. Jumlah responden sebanyak 31 orang yang diambil dengan metode total sampling. Pengumpulan data menggunakan lembar pemeriksaan status gingiva dengan indeks gingiva. Hasil penelitian menunjukkan status gingiva pada 29 pasien $(93,6 \%)$ pengguna GTC termasuk kategori peradangan ringan (indeks gingiva 0,7). Simpulan: Status gingiva pada sebagian besar pasien pengguna gigi tiruan cekat di RSGM PSPDG Fakultas Kedokteran Universitas Sam Ratulangi Manado termasuk dalam kategori peradangan ringan.
\end{abstract}

Kata kunci: status gingiva, gigi tiruan cekat 
Kesehatan gigi dan mulut sering kali bukan menjadi prioritas yang utama bagi sebagian orang. Kenyataan tersebut mengakibatkan minimnya pemahaman dan pengetahuan tentang pentingnya menjaga kesehatan gigi dan mulut menjadi penyebab timbulnya masalah kesehatan gigi dan mulut yang baru. Masalah kesehatan gigi dan mulut yang paling banyak ditemukan di Indonesia yaitu karies dan penyakit periodontal. ${ }^{1,2}$

Masyarakat Indonesia yang menderita masalah kesehatan gigi dan mulut umumnya memanfaatkan pelayanan kesehatan gigi dan mulut untuk melakukan pencabutan gigi. ${ }^{2}$ Salah satu cara untuk mengembalikan fungsi gigi yang hilang karena pencabutan gigi yaitu dengan pemakaian gigi tiruan. ${ }^{3}$ Gigi tiruan cekat (GTC) merupakan salah satu jenis gigi tiruan yang dapat menjadi alternatif untuk menggantikan fungsi-fungsi gigi yang hilang.

Data Riset Kesehatan Dasar (RISKESDAS) tahun 2007 menunjukkan persentase pengguna gigi tiruan cekat di provinsi Sulawesi Utara sebesar $7,1 \%{ }^{4}$ Hal ini menunjukkan bahwa penggunaan gigi tiruan cekat sudah mulai diminati oleh masyarakat. Selain dirasakan seperti gigi sendiri oleh pasien, keuntungan pemakaian gigi tiruan cekat yaitu memiliki kekuatan yang baik saat digunakan pada restorasi besar, mampu untuk membuat gigi terlihat estetik, tidak mudah terlepas atau tertelan serta lebih murah dibandingkan dengan implant gigi. ${ }^{5-7}$

Pemakaian GTC dapat menimbulkan dampak pada jaringan periodontal, antara lain menyebabkan timbulnya kelainan jaringan periodontal seperti gingivitis. Penelitian oleh Sahrini ${ }^{8}$ di RSGM Universitas Hasanuddin menunjukkan gingivitis yang ditimbulkan akibat pemakaian gigi tiruan cekat disebabkan oleh permukaan restorasi yang kasar, keadaan embrasure yang terbuka, dan kontur mahkota yang berlebih dari gigi tiruan. Dengan demikian pemakaian gigi tiruan cekat dapat menimbulkan masalah pada jaringan periodontal apabila dalam pembuatannya tidak memenuhi syaratsyarat dari suatu restorasi. ${ }^{8,9}$

Rumah Sakit Gigi dan Mulut (RSGM) PSPDG Fakultas Kedokteran Universitas Sam Ratulangi merupakan salah satu wadah pelayanan kesehatan gigi dan mulut di kota Manado yang melayani pembuatan GTC. Kasus kehilangan gigi dengan pemasangan GTC dilakukan oleh mahasiswa profesi di RSGM. Dengan demikian perlu adanya evaluasi untuk mengetahui kondisi jaringan gingiva setelah pemasangan GTC.

Penelitian ini bertujuan untuk mengetahui status gingiva pada pasien pengguna gigi tiruan cekat di RSGM PSPDG Fakultas Kedokteran Universitas Sam Ratulangi Manado.

\section{BAHAN DAN METODE PENELITIAN}

Jenis penelitian ini ialah deskriptif dengan desain potong lintang. Penelitian dilaksanakan di RSGM PSPDG Fakultas Kedokteran Universitas Sam Ratulangi Manado pada bulan Juni tahun 2016. Populasi penelitian yaitu seluruh pasien pengguna GTC yang dibuat di RSGM PSPDG Fakultas Kedokteran Universitas Sam Ratulangi Manado sejak bulan Januari 2014 sampai bulan Desember 2015 sebanyak 34 orang. Sampel penelitian yaitu pasien pengguna GTC yang dibuat di RSGM PSPDG Fakultas Kedokteran Universitas Sam Ratulangi Manado sejak bulan Januari 2014 sampai bulan Desember 2015 yang memenuhi kriteria inklusi dan eksklusi. Metode pengambilan sampel yang digunakan yaitu total sampling dengan besar sampel sebanyak 31 responden.

Pengambilan data diperoleh melalui formulir pemeriksaan dari subjek penelitian untuk melihat status gingiva pada pasien pengguna GTC sebagai data primer dan data rekam medik pengguna GTC yang diperoleh di RSGM PSPDG Fakultas Kedokteran Universitas Sam Ratulangi Manado sebagai data sekunder 
HASIL PENELITIAN

Tabel 1. Distribusi responden berdasarkan jenis kelamin

\begin{tabular}{ccr}
\hline $\begin{array}{c}\text { Jenis } \\
\text { kelamin }\end{array}$ & n & \multicolumn{1}{c}{} \\
\hline $\mathrm{L}$ & 20 & 64,5 \\
$\mathrm{P}$ & 11 & 35,5 \\
Total & 31 & 100,0 \\
\hline
\end{tabular}

Tabel 2. Distribusi responden berdasarkan usia

\begin{tabular}{crr}
\hline Usia (tahun) & $\mathbf{n}$ & \multicolumn{1}{c}{$\%$} \\
\hline $17-25$ & 10 & 32,3 \\
$26-35$ & 17 & 54,8 \\
$36-45$ & 3 & 9,7 \\
$46-55$ & 1 & 3,2 \\
Total & 31 & 100,0 \\
\hline
\end{tabular}

Tabel 3. Distribusi responden berdasarkan lama pemakaian GTC

\begin{tabular}{ccr}
\hline $\begin{array}{c}\text { Lama pemakaian } \\
\text { GTC (bulan) }\end{array}$ & $\mathbf{n}$ & $\mathbf{\%}$ \\
\hline$<12$ & 10 & 32,3 \\
$12-24$ & 21 & 67,7 \\
Total & 31 & 100,0 \\
\hline
\end{tabular}

Tabel 4. Distribusi status gingiva berdasarkan indeks gingiva

\begin{tabular}{ccc}
\hline Status gingiva & n & \% \\
\hline Sehat (Skor 0) & 1 & 3,2 \\
Ringan (Skor 0,1-1,0) & 29 & 93,6 \\
Moderat (Skor 1,1-2,0) & 1 & 3,2 \\
Parah (Skor 2,1-3,0) & 0 & 0,0 \\
Total & 31 & 100,0 \\
\hline
\end{tabular}

Tabel 5. Distribusi status gingiva berdasarkan jenis kelamin

\begin{tabular}{ccccccccccc}
\hline \multirow{2}{*}{$\begin{array}{c}\text { Jenis } \\
\text { Kelamin }\end{array}$} & \multicolumn{9}{c}{ Status Gingiva } & \multirow{2}{*}{ Total } \\
\cline { 2 - 10 } & \multicolumn{2}{c}{ Sehat } & \multicolumn{1}{c}{ Ringan } & \multicolumn{2}{c}{ Moderat } & \multicolumn{2}{c}{ Parah } & & \\
\hline & $\mathrm{n}$ & $\%$ & $\mathrm{n}$ & $\%$ & $\mathrm{n}$ & $\%$ & $\mathrm{n}$ & $\%$ & $\mathrm{n}$ & $\%$ \\
\hline $\mathrm{P}$ & 0 & 0,0 & 19 & 61,3 & 1 & 3,2 & 0 & 0,0 & 20 & 64,5 \\
Total & 1 & 3,2 & 10 & 32,3 & 0 & 0,0 & 0 & 0,0 & 11 & 35,5 \\
\hline
\end{tabular}

Tabel 6. Distribusi status gingiva berdasarkan usia

\begin{tabular}{|c|c|c|c|c|c|c|c|c|c|c|}
\hline \multirow{3}{*}{$\begin{array}{c}\text { Usia } \\
\text { (tahun) }\end{array}$} & \multicolumn{8}{|c|}{ Status Gingiva } & \multirow{2}{*}{\multicolumn{2}{|c|}{ Total }} \\
\hline & \multicolumn{2}{|c|}{ Sehat } & \multicolumn{2}{|c|}{ Ringan } & \multicolumn{2}{|c|}{ Moderat } & \multicolumn{2}{|c|}{ Parah } & & \\
\hline & $\mathrm{n}$ & $\%$ & $\mathrm{n}$ & $\%$ & $\mathrm{n}$ & $\%$ & $\mathrm{n}$ & $\%$ & $\mathrm{n}$ & $\%$ \\
\hline $17-25$ & 1 & 3,2 & 9 & 29,0 & 0 & 0,0 & 0 & 0,0 & 10 & 32,3 \\
\hline $26-35$ & 0 & 0,0 & 16 & 51,6 & 1 & 3,2 & 0 & 0,0 & 17 & 54,8 \\
\hline $36-45$ & 0 & 0,0 & 3 & 9,8 & 0 & 0,0 & 0 & 0,0 & 3 & 9,7 \\
\hline $46-55$ & 0 & 0,0 & 1 & 3,2 & 0 & 0,0 & 0 & 0,0 & 1 & 3,2 \\
\hline Total & 1 & 3,2 & 29 & 93,6 & 1 & 3,2 & 0 & 0,0 & 31 & 100,0 \\
\hline
\end{tabular}

Tabel 7. Distribusi status gingiva berdasarkan lama pemakaian GTC

\begin{tabular}{ccccccccccc}
\hline Lama & \multicolumn{9}{c}{ Status Gingiva } & \multirow{2}{*}{ Total } \\
\cline { 2 - 9 } pemakaian & \multicolumn{2}{c}{ Sehat } & \multicolumn{1}{c}{ Ringan } & \multicolumn{2}{c}{ Moderat } & \multicolumn{2}{c}{ Parah } & & \\
\cline { 2 - 10 } GTC (bulan) & $\mathrm{n}$ & $\%$ & $\mathrm{n}$ & $\%$ & $\mathrm{n}$ & $\%$ & $\mathrm{n}$ & $\%$ & $\mathrm{n}$ & $\%$ \\
\hline$<12$ & 0 & 0,0 & 10 & 32,3 & 0 & 0,0 & 0 & 0,0 & 10 & 32,3 \\
$12-24$ & 1 & 3,2 & 19 & 61,3 & 1 & 3,2 & 0 & 0,0 & 21 & 67,7 \\
Total & 1 & 3,2 & 29 & 93,6 & 1 & 3,2 & 0 & 0,0 & 31 & 100,0 \\
\hline
\end{tabular}

\section{BAHASAN}

Distribusi responden pengguna GTC berdasarkan jenis kelamin pada Tabel 1 menunjukkan bahwa jenis kelamin lakilaki merupakan responden yang paling banyak, yaitu sebanyak 20 responden $(64,5 \%)$. Banyaknya jumlah responden berjenis kelamin laki-laki menunjukkan bahwa masih kurangnya kepedulian lakilaki dalam menjaga kesehatan gigi dan 
mulut sehingga resiko kehilangan gigi pada laki-laki lebih besar daripada perempuan. Penelitian yang dilakukan oleh Lessang ${ }^{10}$ menyebutkan bahwa prevalensi penyakit periodontal lebih sering dan lebih parah terjadi pada laki-laki dibandingkan perempuan.

Distribusi responden pengguna GTC berdasarkan usia pada Tabel 2 menunjukkan bahwa responden berusia 26-35 tahun merupakan responden yang terbanyak, yaitu sebanyak 17 responden $(54,8 \%)$. Hal ini mengacu pada syarat dari pembuatan GTC itu sendiri bahwa mahkota klinik harus sudah tumbuh sempurna agar bidang retensi semakin luas pada pemasangan GTC. Responden yang melakukan perawatan dengan penggunaan GTC di RSGM Universitas Sam Ratulangi paling banyak ditemukan berusia 28 tahun. Usia tersebut menunjukkan bahwa mahkota klinik sudah tumbuh sempurna karena masa erupsi gigi yang paling terakhir tumbuh (molar 3) yaitu pada usia 17-21 tahun. Selain itu, syarat dari suatu gigi penyangga (gigi abutment) pada GTC yang baik yaitu memiliki dentin tebal. Ketebalan dentin mengikuti berlanjutnya usia seseorang; makin lanjut usia maka dentinnya akan semakin tebal. ${ }^{11,12}$

Distribusi responden pengguna GTC berdasarkan lama pemakaian GTC pada Tabel 3 menunjukkan bahwa responden yang menggunakan gigi tiruan selama 1224 bulan paling banyak ditemukan, yaitu sebanyak 21 responden $(67,7 \%)$. Responden dalam penelitian ini paling banyak merupakan pasien lama, sebab dalam setahun terakhir jumlah pasien yang diindikasikan menggunakan GTC belum semuanya di insersi. Hal ini berkaitan dengan rentang waktu pembuatan GTC yang harus memenuhi syarat mekanis, fisiologik, hygiene, dan estetik. Penelitian yang dilakukan Lesmana ${ }^{9}$ tentang faktorfaktor periodontal dengan GTC menjelaskan bahwa upaya terbaik untuk membantu menjaga kesehatan gigi dan jaringan mulut pasien sebelum dan sesudah pemakaian GTC yaitu tindakan pencegahan terjadinya kelainan dengan pemeriksaan awal secara teratur serta pembuatan GTC yang harus memenuhi syarat. ${ }^{5,9}$

Distribusi status gingiva berdasarkan indeks gingiva pada Tabel 4 menunjukkan bahwa paling banyak ditemukan yaitu responden yang memiliki status gingiva ringan sebanyak 29 responden $(93,6 \%)$. Rata-rata skor gingiva yang didapatkan yaitu 0,7 dan sebagian besar peradangan ditemukan pada gingiva dari gigi penyangga tempat melekatnya GTC. Hasil serupa juga ditunjukkan dalam penelitian yang dilakukan Andhira ${ }^{13}$ mengenai kesehatan gingiva pada pengguna GTC di Pulau Kodingareng bahwa terdapat lebih banyak pengguna gigi tiruan cekat yang memiliki status gingiva ringan yaitu sebesar $75 \%$.

Distribusi status gingiva berdasarkan jenis kelamin pada Tabel 5 menunjukkan bahwa jenis kelamin laki-laki paling banyak mengalami peradangan gingiva ringan yaitu sebanyak 19 responden (61,3\%). Hal ini dikarenakan jumlah responden pada penelitian ini sebagian besar berjenis kelamin laki-laki. Namun, penelitian yang dilakukan Sahrini ${ }^{8}$ pada pengguna GTC yang mengalami gingivitis di RSGM Universitas Hasanuddin mendapatkan jumlah yang sama untuk responden berjenis kelamin laki-laki dan perempuan $(50 \%)$. Berbeda dengan penelitian Andhira ${ }^{13}$ mengenai kesehatan gingiva pada pengguna GTC di Pulau Kodingareng yang menunjukkan jumlah responden berjenis kelamin perempuan lebih banyak daripada laki-laki yaitu sebesar $75 \%$.

Distribusi status gingiva berdasarkan usia pada Tabel 6 menunjukkan bahwa responden berusia 26-35 tahun merupakan responden yang paling banyak mengalami peradangan gingiva ringan, yaitu sebanyak 16 responden $(51,6 \%)$. Usia responden yang ditunjukkan dari hasil penelitian ini tergolong pada usia produktif sehingga aktivitas yang padat dari pekerjaan yang dimiliki dapat memengaruhi kondisi kesehatan rongga mulut. Hasil ini tidak berbeda jauh dengan penelitian yang dilakukan oleh Sahrini $^{8}$ pada pengguna 
GTC di RSGM Universitas Hasanuddin yaitu sampel yang paling banyak yaitu berusia 27-31 tahun sebesar $40 \%$.

Distribusi status gingiva berdasarkan lama pemakaian GTC pada Tabel 7 menunjukkan bahwa responden yang memakai GTC selama 12-24 bulan paling banyak mengalami peradangan gingiva ringan, yaitu sebanyak 19 responden $(61,3 \%)$. Penggunaan gigi tiruan dengan rentang waktu yang cukup lama dapat memengaruhi kondisi jaringan sekitar terutama pada bagian yang berhubungan langsung dengan gingiva. Tingkat keparahan pada peradangan gingiva tergantung kepedulian dan perilaku yang benar dari individu dalam menjaga kesehatan rongga mulut. Menurut Rahmayani et al. ${ }^{14}$ dalam penelitiannya mengenai perilaku dalam memelihara kebersihan gigi tiruan mengatakan bahwa pemakaian gigi tiruan menyebabkan mukosa di bawah gigi tiruan akan tertutup dalam jangka waktu yang lama. Kondisi kesehatan rongga mulut pada pengguna GTC di RSGM Universitas Sam Ratulangi sebagian besar masih kurang baik. Jika pemakaian gigi tiruan tidak disertai dengan kebersihan mulut yang baik dapat mengakibatkan terjadinya akumulasi plak yang merupakan penyebab terjadinya gingivitis.

Sebagian besar responden pada penelitian ini mengalami peradangan ringan diikuti pembengkakkan pada area sekitar gigi penyangga dari GTC. Inflamasi gingiva yang terjadi pada sekeliling GTC terjadi akibat peningkatan retensi plak. Desain gigi tiruan yang kurang baik dapat meningkatkan penumpukan sisa makanan pada bagian yang berkontak dengan permukaan gigi asli, yang mengganggu aksi self-cleansing oleh lidah dan pipi selama proses pengunyahan. $^{15}$

Gingivitis dapat ditemukan pada pengguna gigi tiruan yang jarang memerhatikan faktor kebersihan rongga mulut terutama apabila GTC yang digunakan memiliki permukaan kasar sehingga dapat melukai gusi dan menyebabkan radang. Sejak tahun 1956 sampai 1974 banyak ilmuwan membuktikan bahwa permukaan restorasi yang kasar merupakan retensi plak. Hal ini selaras dengan penelitian Lesmana $^{9}$ mengenai faktor-faktor periodontal dengan GTC menjelaskan bahwa masalah yang ditimbulkan karena pemakaian GTC seperti gingivitis dapat timbul bila restorasi pada GTC tersebut tidak memenuhi syaratsyarat utama dalam pembuatannya yaitu, syarat mekanis, fisiologik, hygiene dan estetik. Hal ini juga didukung oleh Sahrini ${ }^{8}$ dalam penelitiannya mengenai faktorfaktor yang menyebabkan terjadinya gingivitis akibat pemakaian GTC pada pengunjung di RSGM Universitas Hasanuddin Makasar bahwa gingivitis yang terjadi akibat pemakaian GTC dipengaruhi oleh faktor permukaan restorasi yang kasar, keadaan embrasure yang terbuka, dan kontur mahkota yang berlebih dari gigi tiruan. Oleh sebab itu, pembuatan GTC harus memerhatikan faktor adaptasi tepi restorasi yang berhubungan dengan gingiva agar tidak menekan atau mengiritasi gingiva, harus halus, tidak tajam dan tidak berlebih (overcontoured). ${ }^{5,8,9}$

\section{SIMPULAN}

Status gingiva pada pasien pengguna gigi tiruan cekat di RSGM PSPDG Fakultas Kedokteran Universitas Sam Ratulangi Manado termasuk dalam kategori peradangan ringan.

\section{SARAN}

1. Bagi RSGM Universitas Sam Ratulangi Manado perlu melakukan kontrol secara periodik minimal enam bulan sekali pada pasien setelah penggunaan gigi tiruan cekat untuk mencegah terjadinya peradangan pada gingiva, sehingga GTC benar-benar dapat beradaptasi dengan baik dalam rongga mulut. Selain itu, perlu untuk membuat data rekam medik yang berisi informasi setiap pasien secara komputerisasi agar mempermudah dalam mengisi dan mengakses rekam medik serta menghindari kesalahan penulisan 
nomor rekam medik yang ada.

2. Bagi pasien yang menggunakan GTC perlu untuk menjaga kesehatan gigi dan mulut seperti menyikat gigi setelah makan pagi dan sebelum tidur malam dengan teknik yang benar serta kontrol minimal enam bulan sekali ke dokter gigi baik di sarana kesehatan seperti RSGM, puskesmas maupun praktik pribadi.

3. Penelitian ini dapat menjadi acuan referensi bagi penelitian selanjutnya mengenai penggunaan GTC yang berdampak pada gingiva maupun pada jaringan periodontal lainnya dengan jumlah responden yang lebih besar.

\section{DAFTAR PUSTAKA}

1. Kementerian Kesehatan Republik Indonesia. Situasi Kesehatan Gigi dan Mulut. Infodatin Pusat Data dan Informasi Kementrian Kesehatan RI, 2014; p.1

2. Wisatya MR, Hadnyanawati $H$, Suhartini. Analisis perbandingan tingkat kepuasan pasien dalam pemakaian protesa gigi tiruan lepasan yang dibuat tukang gigi dan dokter gigi di Kabupaten Jember [Skripsi]. Jember: Fakultas Kedokteran Gigi Universitas Jember; 2014.

3. Tarigan S. Pasien prostodonsia lanjut usia: Beberapa pertimbangan dalam perawatan. Pidato pengukuhuan guru besar tetap. Medan: Universitas Sumatera Utara, 2005: p.3

4. Badan Penelitian dan Pengembangan Kesehatan Departemen Kesehatan Republik Indonesia. Riset Kesehatan Dasar (RISKESDAS) 2007. Laporan Nasional. Jakarta. 2008. h.146 [cited 2016 April 14]. Available from URL: http:www.scribd.com/doc/82922543/ laporanNasional-Riskesdas-2007

5. Indrastuti M. Bahan Ajar Prostodonsia II Gigi Tiruan Cekat (GTC). Universitas Gadjah Mada. 2012; p. 2-15. [cited 2016 April 15]; Available from URL: http://elisa.ugm.ac.id/ community/show/prostodensiaii/\#!/section/12775/1461737753
6. Popper JR. Restorative prosthodontics. Prosthodontics of the Tri-Cities. 2015. [cited 2016 April 14]; Available from URL: http://johnrpopperdds.com/restorativ e-prosthodontics

7. Kalyana K. Sinus lifting untuk pemasangan implan pada rahang atas [Skripsi]. Medan: Fakultas Kedokteran Gigi Universitas Sumatera Utara; 2012.

8. Sahrini. Faktor-faktor yang menyebabkan terjadinya gingivitis akibat pemakaian gigi tiruan cekat (GTC) pada pengunjung di RSGM Universitas Hasanuddin Makassar [Skripsi]. Makassar: Fakultas Kedokteran Gigi Universitas Hasanuddin; 2015.

9. Lesmana RA. Faktor-faktor periodontal dengan gigi tiruan cekat. Jurnal Kedokteran Gigi Universitas Indonesia. 1999;6(3):35-40.

10.Lessang R. Penatalaksanaan Faktor Resiko untuk Perawatan Periodontal Yang Baik. 2012. [cited 2016 Juli 17]; Available from URL: http://mitrakeluarga.com/bekasi/pena talaksanaan-faktor-resiko-untukperawatan-periodontal-yang-baik/

11.Prajitno HR. Ilmu Geligi Tiruan Jembatan Pengetahuan Dasar dan Rancangan Pembuatan. Jakarta: EGC, 1991; p.15,21,36.

12.Harshanur IW. Anatomi Gigi. Juwono L, editor. Jakarta: EGC, 1991; p. 215.

13.Andhira AD. Kesehatan gingiva pada pengguna gigi tiruan cekat di Pulau Kodingareng. Makassar: Fakultas Kedokteran Gigi Universitas Hasanuddin. 2011. h.34 [cited 2016 Agustus 20]; Available from URL: http://repository.unhas.ac.id/handle/1 23456789/1022? show=full

14. Rahmayani L, Herwanda, Idawani $M$. Perilaku pemakai gigi tiruan terhadap pemeliharaan kebersihan gigi tiruan lepasan. Jurnal PDGI. 2013;26(3):84

15. Fernatubun CA, Pangemanan DHC, Wowor VNS. Gambaran kerusakan gigi penyangga pada pengguna gigi tiruan sebagian lepasan di Kelurahan Batu Kota. e-GiGi. 2015; 3(1):91-2. 